\title{
PASAR dan PEMASARAN
}

Mata Kuliah Kewirausahaan

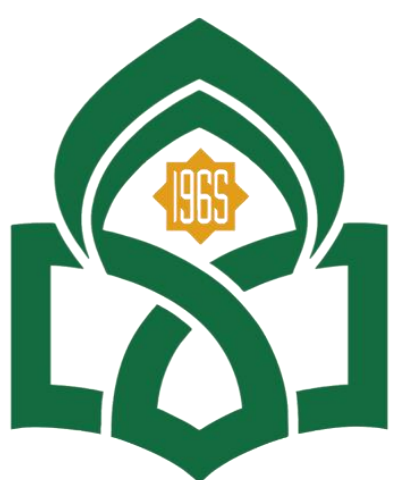

UNIVERSITAS ISLAM NEGERI

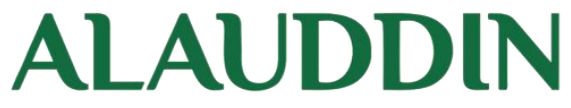

M A K A S S A R

OLEH :

RANI RAHMAN ADY KAMPA

90500120094

PSY-C

PROGRAM STUDI PERBANKAN SYARIAH

FAKULTAS EKONOMI DAN BISNIS ISLAM

UNIVERSITAS ISLAM NEGERI ALAUDDIN MAKASSAR

TAHUN AJARAN 2021/2022 


\section{KATA PENGANTAR}

Puji syukur kita panjatkan kepada Allah SWT atas rahmat dan karunia-Nya saya dapat menyelesaian makalah yang berjudul PASAR dan PEMASARAN. Makalah ini disusun untuk memenuhi tugas mata kuliah Kewirausahaan.

Saya berharap makalah ini dapat berguna bagi saya dan pembaca. Semoga Makalah ini dapat menambah ilmu dan pengetahuan kita mengenai Pasar dan Pemasaran.. Saya menyadari bahwa dalam penulisan makalah ini masih terdapat banyak kekurangan. Oleh karena itu saya mengharapkan saran dan kritik yang membangun untuk menyempurnakan makalah ini menjadi lebih baik lagi.

Makassar, 27 November 2021

Penulis 
DAFTAR ISI

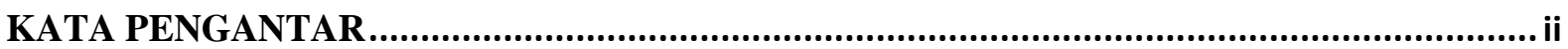

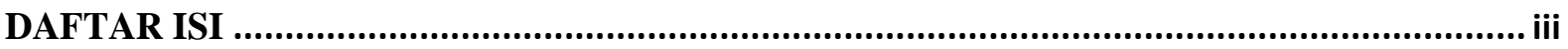

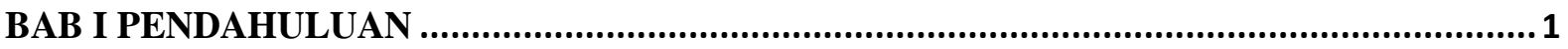

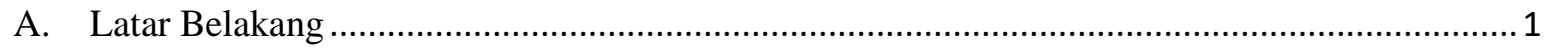

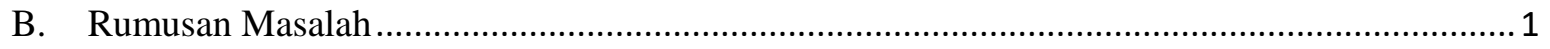

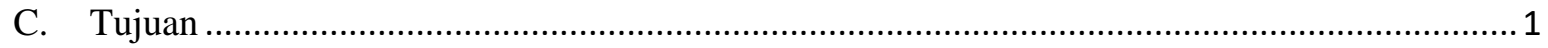

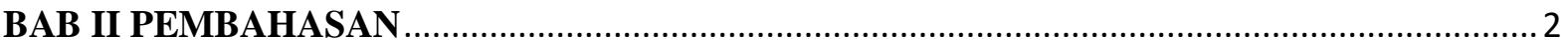

A. Pengertian Pasar dan Pemasaran ..................................................................................... 2

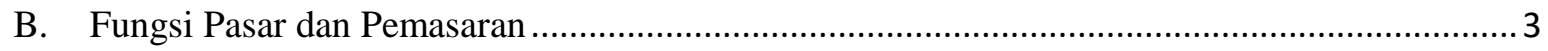

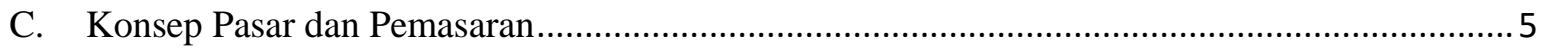

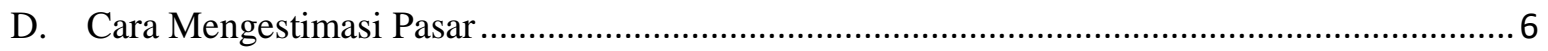

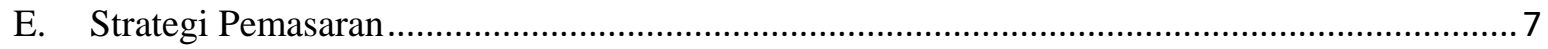

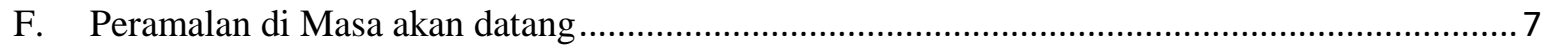

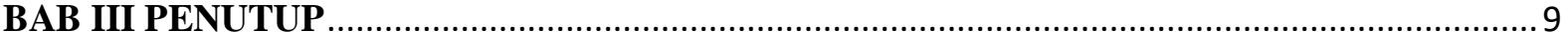

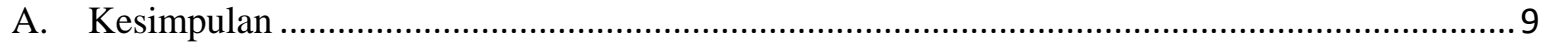

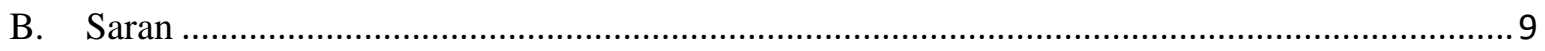

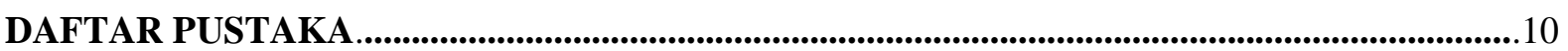




\section{BAB I \\ PENDAHULUAN}

\section{A. Latar Belakang}

Kata pasar dan pemasaran sering sekali didengar ataupun kita jumpai dikehidupan sehari hari. Pasar adalah tempat terjadinya transaksi jual beli (penjualan dan pembelian) yang dilakukan oleh penjual dan pembeli yang terjadi pada waktu dan tempat tertentu. Selain itu Pasar secara umum diartikan sebagai tempat penjual menawarkan barang atau jasa sesuai taksiran harga penjual serta pembeli mendapatkan barang atau jasa sesuai dengan taksiran harga pembeli. Pengertian pasar dalam ilmu ekonomi lebih konseptual, yakni bertemunya permintaan dan penawaran. Dengan demikian sebuah pasar tidak harus dikaitkan dengan suatu tempat. Sedangkan Pemasaran adalah sebagai suatu proses sosial dan managerial yang membuat individu dan kelompok memperoleh apa yang mereka butuhkan dan inginkan lewat penciptaan dan pertukaran timbal balik produk dan nilai dengan orang lain. Nilai ekonomi itu sendiri menentukan harga barang dan jasa. Faktor penting dalam menciptakan nilai tersebut yaitu :

1. Produksi

2. Pemasaran

3. Konsumsi

Hal inilah yang membuat hubungan antara pasar dan pemasaran sangatlah berkaitan karena berhubungan antara penjual dan pembeli.
B. Rumusan Masalah
1. Pengertian Pasar dan Pemasaran
2. Fungsi Pasar dan Pemasaran
3. Konsep Pasar dan Pemasaran
4. Cara Mengestimasi Pasar
5. Strategi Pemasaran
6. Peramalan dimasa akan datang
C. Tujuan

1. Untuk Mengetahui pengertian pasar dan pemasaran

2. Untuk Mengetahui Fungsi pasar dan pemasaran

3. Untuk Mengetahui konsep pasar dan pemasaran

4. Untuk Mengetahui Cara mengestimasi pasar

5. Untuk Mengetahui Strategi Pemasaran

6. Untuk Mengetahui Peramalan dimasa akan datang 


\section{BAB II \\ PEMBAHASAN}

\section{A. Pengertian Pasar dan Pemasaran}

Pasar sebagai tempat dimana para pihak bertemu dan bertukar barang, layanan, dan informasi mereka untuk dipertimbangkan. Pembelian dan penjualan komoditas antar pihak dikenal sebagai transaksi. Dua pihak yang terlibat dalam pertukaran adalah pembeli dan penjual. Transaksi dapat dilanjutkan, baik secara langsung atau melalui perantara seperti agen atau institusi. Ada banyak pembeli dan penjual di pasar. Mereka memainkan peran penting dalam menetapkan harga barang dan jasa. Pembeli memutuskan permintaan, sedangkan penjual menentukan persediaan. Ini adalah pengaturan dimana perdagangan mudah disimpulkan, dan sumber daya dialokasikan, di antara anggota masyarakat yang berbeda.Pasar saat ini, tidak terbatas pada lokasi fisik saja, melainkan telah memiliki cakupan yang luas termasuk juga pasar media hingga pasar internet (e-commerce). Sedangkan Pemasaran adalah suatu proses menyeluruh, terpadu, dan terencana, yang dilakukan oleh sebuah organisasi atau institusi dalam melakukan usaha agar mampu mengakomodir permintaan pasar dengan cara menciptakan produk bernilai jual, menentukan harga, mengkomunikasikan, menyampaikan, dan saling bertukar tawaran yang bernilai bagi konsumen, klien, mitra, dan masyarakat umum.

Adapun menurut para ahli Pemasaran yaitu :

1. John Westwood

Menurut John Westwood, pengertian pemasaran adalah sebuah usaha terpadu yang dilakukan untuk memenuhi kebutuhan konsumen dan memberikan keuntungan atau laba kepada perusahaan.

2. Tung Dasem Waringin

Menurut Tung Desem Waringin, pengertian pemasaran adalah media untuk mengkomunikasikan sebuah nilai tambah yang lebih tinggi.

3. Philip Kotler

Menurut Kotler, pengertian pemasaran adalah aktivitas sosial dan sebuah pengaturan yang dilakukan oleh perorangan ataupun sekelompok orang dengan tujuan untuk mendapatkan tujuan mereka dengan jalan membuat produk dan menukarkannya dengan besaran nominal tertentu ke pihak lain.

4. Jay Abraham

Menurut Jay Abraham, pengertian pemasaran adalah sebuah media untuk mencapai kesuksesan dengan cara memberikan pelayanan peling baik kepada konsumen.

5. William J. Stanton

Menurut William J. Stanton, definisi pemasaran adalah sistem keseluruhan dari berbagai kegiatan bisnis atau usaha yang ditujukan untuk merencanakan, menentukan harga barang atau jasa, mempromosikannya, mendistribusikannya, dan bisa memuaskan konsumen.

6. Joe F. Hair dan Carl McDaniel Menurut Hair dan Mc. Daniel, pengertian pemasaran adalah proses perencanaan dan pelaksanaan konsepsi, penetapan harga promosi dan distribusi gagasan, barang dan jasa untuk menciptakan pertukaran yang memuaskan konsumen dan tercapainya tujuan organisasi.

7. Basu Swastha Dharmamesta dan T. Hani Handoko

Menurut Basu Swastha Dharmamesta dan Hani Handoko, pengertian pemasaran adalah proses kegiatan perencanaan dalam pengelolaan barang dan jasa, penetapan banderol harga barang dan jasa tersebut, hingga proses promosi maupun pendistribusiannya, dimana keseluruhan proses pemasaran bertujuan untuk memenuhi kebutuhan maupun memperoleh laba. 


\section{B. Fungsi Pasar dan Pemasaran Fungsi Pasar}

\section{Sarana Distribusi}

Fungsi utama pasar adalah tempat di mana proses penjualan yang baik terjadi, baik bagi produsen maupun konsumen. Dengan pasar, produsen dapat memasarkan dan menjual produk mereka dan konsumen dapat memperoleh kebutuhan mereka dari barang di pasar. Pasar pada dasarnya adalah jembatan antara produsen dan konsumen. Produsen yang telah membuat barang dapat menjualnya dan menawarkannya kepada konsumen dan konsumen yang membutuhkan. Ini bisa didukung oleh keberadaan barang-barang ini.

\section{Pembentuk Harga atau Penentu Nilai}

Fungsi pasar untuk menetapkan dan menetapkan harga dengan tujuan di semua tempat dan kelompok harga tentu saja sama dengan kondisi yang berlaku, mis. B. Harga yang disesuaikan dengan kondisi geografis, kondisi masyarakat, kondisi ekonomi dalam bentuk penawaran dan permintaan dan banyak lainnya. Itu semua berada di area yang luas, sementara di area yang kecil fungsi pasar yang membentuk harga terlihat ketika ada proses negosiasi antara pembeli dan penjual yang menghasilkan harga minimal tetapi tetap menguntungkan bagi produsen atau penjual tersebut.

\section{Sarana Untuk Promosi}

Pasar telah menjadi salah satu tempat paling efektif untuk beriklan. Karena ada banyak orang dan orang banyak di pasar yang mencari kebutuhan mereka. Ini telah membuat produsen alat untuk meluncurkan produknya dengan harapan bahwa banyak konsumen akan tertarik dengan produk ini. Dengan pasar, produsen akan mendapatkan bantuan dan bantuan dengan iklan, yang biasanya membutuhkan banyak biaya iklan untuk dimasukkan dalam media cetak atau iklan media elektronik, tetapi ketika mereka berada di pasar, produsen tidak perlu menghabiskan banyak, cukup pergi di pasar dan mempresentasikan dan menjual produk mereka. Ini adalah inti dari fungsi pasar sebagai media iklan, di mana produsen dapat memperkenalkan produknya tanpa kesulitan dan dalam kondisi yang rumit.

\section{Tempat Mencari Keuntungan}

Di pasar ini, produsen dapat menjual barang-barang mereka, yang memberi mereka penghasilan. Pasar di sini sangat membantu karena tidak semua pihak harus membangun jaringan konsumen dari awal atau merasa sulit menemukan konsumen, tetapi masalahnya akan hilang di pasar karena sudah ada satu kesatuan antara produsen dan konsumen di pasar yang semuanya berjuang untuk saling menguntungkan dan bermoral.

\section{Pembentukan Kreatifitas}

Kehadiran pasar dapat menghasilkan tingkat kreativitas yang tinggi bagi produsen dan konsumen. Bagi produsen kreativitas dan inovasi harus dilakukan untuk selalu membujuk konsumen untuk membeli produk mereka. Selain itu, sesuatu yang baru harus diciptakan untuk tetap kompetitif dan bertahan di pasar. Sejauh menyangkut konsumen, kreativitas mereka dilatih untuk melatih kepekaan mereka dalam memilih dan memutuskan hasil produksi atau barang sesuai dengan kebutuhan mereka.

\section{Mempererat Tali Silaturrahmi}

Pasti akan ada komunikasi atau interaksi antara pihak-pihak yang berkepentingan antara produsen dan produsen dan antara produsen dan konsumen di pasar ketika transaksi sedang berlangsung. Tidak menyadari bahwa hal yang sederhana bisa menjadi hal yang manis, yaitu persaudaraan yang lebih dekat atau persahabatan antar individu. 


\section{Melatih Daya Juang dan Saing}

Ketika seseorang terjun ke pasar, mereka harus siap bertarung dan bersaing dengan situasi dan kondisi di sekitar mereka, terlepas dari status, kelas, dan lainnya. Di pasar yang sama, semuanya tergantung pada apa yang sedang dilakukan. Jika Anda ingin sukses, Anda akan bekerja keras dan melakukan semua yang Anda bisa untuk tetap di koridor yang benar. Dan bagi mereka yang malas atau pasif, mereka juga tidak akan mendapatkan apa-apa. Bagi mereka yang terlatih dan terbiasa berkelahi dan berkompetisi, ketika mereka meninggalkan pasar, mereka menjadi individu yang kuat yang mampu menyelesaikan masalah dalam hidup mereka.

\section{Sarana Pembangunan Nasional}

Pasar terkait erat dengan pembangunan nasional, karena bahan, peralatan, atau sumber daya lain yang tersedia di pasar dapat berfungsi sebagai dasar untuk pembangunan. Pasar juga merupakan salah satu penyedia dana untuk pengembangan yang ada, yaitu pajak yang mereka bayar. Hal inilah yang mendasari fungsi pasar untuk sarana pembangunan nasional.

\section{Meningkatkan Pemasukan Negara}

Kegiatan produksi menghasilkan uang, yang harus dibayar sebagian untuk pajak, kegiatan konsumsi juga menghasilkan uang, yang pada gilirannya harus ditunda untuk membayar sewa untuk lokasi atau sewa tempat dan banyak lainnya. Orang bisa mengatakan bahwa pendapatan negara akan membaik jika kondisi pasar negara itu baik. Pada prinsipnya, keberadaan pasar dapat mendukung pemerintah dalam memenuhi tugasnya untuk mencapai tujuan kebaikan bersama. Ini membuat kondisi dan kondisi ekonomi negara stabil dan dominan.

\section{Mengontrol Kegiatan Ekonomi}

Pasar ini sangat membantu bagi pemerintah atau negara ketika datang untuk mengendalikan semua kegiatan dan aliran ekonomi negara. Kita dapat membayangkan bahwa konsentrasi pemerintah akan terbagi jika tidak ada pasar, dan ini menyulitkan mereka untuk mengendalikan dan mengatasi masalah yang muncul. Dengan cara ini, pasar dapat membantu pemerintah fokus pada pengelolaan aliran ekonomi, dengan pemantauan terfokus pada satu titik.

\section{Fungsi Pemasaran}

\section{Pengenalan Produk}

Pengenalan menjadi fungsi utama dari sebuah pemasaran yang dilakukan oleh perusahaan. Dengan adanya pemasaran, produk akan lebih mudah dikenal oleh pelanggan. Pemasar harus menonjolkan keunggulan dari produk yang di pasarkan. Sehingga bisa lebih menarik perhatian dibanding produk pesaing.

\section{Riset}

Riset memungkinkan pemasaruntuk mendapatkan informasi yang tepat mengenai pasar target sebuah produk. Beberapa hal yang biasanya harus diriset adalah kepopuleran, usia, jenis kelamin kebutuhan hingga keinginan dan lain sebagainya. Nantinya produk yang diproduksi bisa disesuaikan dengan apa yang sesuai dengan target pasarnya.

\section{Distribusi}

Dengan distribusi yang baik, akan memastikan bahwa produk dapat mudah dipindahkan dari lokasi produksi ke pasar luas menggunakan jalur darat, air dan laut. Selain itu juga memastikan bahwa produk dapat dengan mudah didapatkan oleh pelanggan. Sebagai pemasar juga harus merencanakan segala sesuatunya seperti armada, keuangan dalam proses distribusi. 


\section{Layanan Purnajual}

Dalam sebuah penjualan, layanan setelah penjualan memang sangat dibutuhkan. Pemasar harus membantu pelanggan setelah mereka membeli produk. Misalnya seperti produk mesin, pelanggan mungkin akan merasa kesulitan ketika menemukan masalah pada mesin yang telah mereka beli. Tugas pemasar, memastikan dan membantu agar mesin itu berjalan dengan semestinya.

\section{Konsep Pasar dan Pemasaran}

\section{Konsep Pasasr}

\section{Konsep Pasar Monopoli}

Konsep pasar monopoli terjadi saat sebuah pasar dikuasai hanya oleh satu produsen. Kondisi ini terjadi saat sebuah perusahaan atau pihak menguasai sumber daya atau dalam kondisi tertentu, hanya dia yang dapat menyediakan sumber daya tertentu.

\section{Konsep Pasar Monopsoni}

Kebalikan dari monopoli, monopsoni adalah kondisi di mana seorang konsumen menguasai pasar. Ini terjadi dalam kondisi saat seorang pembeli memiliki daya beli yang tinggi dan posisi tawar yang tinggi.

\section{Konsep Pasar Oligopoli}

Konsep pasar oligopoli kurang lebih serupa dengan konsep pasar monopoli. Hanya saja, apabila konsep pasar monopoli hanya memiliki satu penjual yang mendominasi, pasar oligopoli memiliki beberapa penjual yang mendominasi.

\section{Konsep Pasar Oligopsoni}

Pasar oligopsoni merupakan pasar yang didominasi oleh lebih dari satu konsumen yang punya daya tawar dan daya beli tinggi. Konsepnya sama dengan monopsoni, di mana penjual tak punya posisi tawar tinggi sehingga 'menyerah' pada tawaran pembeli.

\section{Konsep Pasar Persaingan Sempurna}

Pasar persaingan sempurna adalah kondisi pasar di mana pembeli dan penjual sama-sama punya posisi tawar. Bukan hanya itu saja, konsep pasar persaingan sempurna juga memungkinkan setiap orang untuk menjadi konsumen atau produsen, dan memilih barang yang sesuai dengan kantong atau kebutuhan mereka.Pasar persaingan sempurna adalah pasar ideal yang adil bagi setiap pihak. Namun, dalam sebuah pemerintahan oligarki, terkadang pasar persaingan sempurna sengaja ditiadakan.

\section{Konsep Pemasaran}

\section{Konsep produksi (Production)}

Konsep produksi merupakan salah satu konsep pemasaran paling awal dimana perusahaan berfokus pada efisiensi proses produksi. Seperti yang sudah kita ketahui, pada umumnya konsumen akan menyukai suatu produk dengan kualitas yang baik dengan harga yang terjangkau. Selain itu, konsep produksi ini juga fokus akan ketersediaan produk. Jadi, untuk mencapai hal tersebut, maka perusahaan perlu mengoptimalkan proses produksi yang akan dilakukan. 


\section{Konsep produk (Product)}

Konsep produk mengusung gagasan bahwa konsumen akan menyukai produk dengan kualitas dan kinerja yang baik. Hal ini menunjukkan bahwa pelanggan akan mencari alternatif yang inovatif dan selalu mencari yang terbaik dari apa yang saat ini tersedia di pasar. Selain itu, dalam konsep ini, diasumsikan bahwa konsumen juga akan tetap loyal jika mereka mendapat banyak pilihan dan memperoleh manfaat dari produk yang digunakan.

\section{Konsep penjualan (Selling)}

Konsep pemasaran yang selanjutnya adalah konsep penjualan atau selling. Pada konsep ini, perusahaan akan berorientasi pada penjualan. Artinya, perusahaan dapat mengembangkan suatu produk dan menjualnya ke target market tanpa mempertimbangkan kebutuhan atau keinginan konsumen. Konsep penjualan meyakini bahwa pelanggan akan membeli produk saat perusahaan melakukan penjualan secara agresif.

\section{Konsep Pemasaran (Marketing)}

Perusahaan yang mempercayai konsep pemasaran ini, akan menempatkan konsumen sebagai fokus utama mereka. Mereka akan memahami apa yang menjadi kebutuhan dan keinginan konsumen serta menjalankan strategi pemasaran sesuai dengan riset pasar mulai dari konsepsi produk hingga penjualan. Tidak hanya itu saja, ketika penjualan sudah dimulai, perusahaan akan melakukan penelitian lebih lanjut untuk mengetahui feedback konsumen. Selain itu perusahaan juga akan mencari tahu apakah perlu dilakukan suatu perbaikan untuk produk tersebut.

\section{Konsep Pemasaran Sosial (Societal Marketing)}

Konsep pemasaran sosial adalah konsep pemasaran yang relatif baru. Sebagian besar orang beranggapan bahwa konsep pemasaran sosial memiliki pemikiran yang selangkah lebih maju daripada konsep pemasaran yang sebelumnya sudah kita bahas di point 4 . Anggapan tersebut muncul karena perusahaan yang mengusung konsep ini tidak hanya berusaha untuk memenuhi kebutuhan konsumennya namun juga menekankan pada kesejahteraan masyarakat.

\section{Cara Mengestimasi Pasar}

Untuk mengetahui besarnya pasar nyata, potensi dasar dan total pasar dalam suatu wilayah perlu dilakukan penelitian terlebih dahulu. Penelitian dilakukan untuk memperoleh data, baik dengan metode yang relevan seperti melalui survei, kuesioner atau dengan mengumpulkan data skunder dari berbagai sumber. Kemudian untuk mengetahui pasar nyata dan pasar potensi dapat digunakan beberapa metode antara lain metode pendapat, metode eksperimen dan metode survei. Pertumbuhan penduduk dan transportasi masyarakat juga menjadi pertimbangan, misalnya kehadiran perumahan atau perkantoran di suatu lokasi juga sangat menunjang. Demikian juga adanya penambahan jalur transportasi serta meningkatnya pendapatan masyarakat juga harus menjadi pertimbangan lebih lanjut. 


\section{E. Strategi Pemasaran}

Strategi pemasaran adalah pengambilan keputusan-keputusan tentang biaya pemasaran, bauran pemasaran, alokasi pemasaran dalam hubungan dengan keadaan lingkungan yang diharapkan dan kondisi persaingan. Dalam strategi pemasaran, ada tiga faktor utama yang menyebabkan terjadinya perubahan strategi dalam pemasaran yaitu :

a. Daur hidup produk

Strategi harus disesuaikan dengan tahap-tahap daur hidup, yaitu tahap perkenalan, tahap pertumbuhan, tahap kedewasaan dan tahap kemunduran.

b. Posisi persaingan perusahaan di pasar

Strategi pemasaran harus disesuaikan dengan posisi perusahaan dalam persaingan, apakah memimpin, menantang, mengikuti atau hanya mengambil sebagian kecil dari pasar.

c. Situasi ekonomi

Strategi pemasaran harus disesuaikan dengan situasi ekonomi dan pandangan kedepan, apakah ekonomi berada dalam situasi makmur atau inflasi tinggi.

Strategi pemasaran didasarkan atas 5 (lima) konsep strategi sebagai berikut :

- $\quad$ Segmentasi Pasar

- $\quad$ Market Positioning

- $\quad$ Market Entry Strategy.

- $\quad$ Marketing Mix Strategy

- $\quad$ Timing Strategy

\section{F. Peramalan di Masa akan datang}

Peramalan merupakan pengetahuan dan seni untuk memperkirakan apa yang akan terjadi di masa yang akan datang pada saat sekarang. Peramal harus mencari data dan informasi masa lalu. Data dan informasi masa lalu merupakan perilaku yang terjadi di masa lalu dengan berbagai kondisi pada saat itu. Kondisi yang menyebabkan perilaku data dan informasi tersebut bisa dijadikan acuan bagi kondisi sekarang dan di masa yang akan datang. Hal ini perlu dilakukan mengingat di masa yang akan datang penuh dengan ketidakpastian.

Untuk melakukan peramalan permintaan di masa yang akan dating dapat dilakukan dengan cara sebagai berikut :

1. Survei niat pembeli

2. Gabungan pendapat tenaga penjual

3. Pendapat ahli

4. Metode tes pasar analisis deret waktu

5. Analisis permintaan secara statistik. 
Penyusunan ramalan dapat dilakukan atas dasar, antara lain :

1. Apa kata orang, penelitian atas pendapat pembeli, tenaga penjual, dan pendapat para ahli.

2. Apa yang dilakukan orang, uji pasar, dan tanggapan pembeli.

3. Apa yang telah dilakukan orang, perilaku pembeli dimasa lalu, dengan deret waktu atau analisis regresi.

Langkah-Langkah Peramalan

Agar peramlan memberikan hasil yang memuaskan, maka haruslah mengikuti prosedur atau langkah-langkah yang telah ditetapkan dalam peramalan. Dengan mengikuti setiap langkah yang telah ditetapkan paling tidak dapat menghindarai kesalahan, sehingga hasil ramalan tidak perlu diragukan.

Secara umum langkah-langkah yang dilakukan dalam peramalan sebagai berikut :
a. Mengumpulkan data
b. Mengolah data
c. Menentukan metode peramalan
d. Memproyeksikan data
e. Mengambil keputusan
2. Jenis-jenis Metode Peramalan
1. Deret Waktu (Time Series).
2. Sebab Akibat (causal methods) 


\section{BAB III \\ PENUTUP}

\section{A. Kesimpulan}

Pasar dan Pemasaran merupakan hal yang saling berhubungan yang dimana Pasar adalah tempat terjadinya transaksi antara penjual dan pembeli. Pemasaran dapat diartikan sebagai upaya untuk menciptakan dan menjual produk kepada berbagai pihak dengan maksud tertentu. Pemasaran berusaha menciptakan dan mempertukarkan produk baik barang maupun jasa kepada konsumen di pasar.Segmentasi pasar artinya membagi pasar menjadi beberapa kelompok pembeli yang berbeda yang mungkin memerlukan produk atau marketing mix yang berbeda pula. Segmentasi pasar dilakukan agar sasaran penjualan produk tepat sesuai dengan kebutuhan pasar.

\section{B. Saran}

Dalam penyusunan makalah ini, saya menyadari bahwa masih banyak kekurangan yang perlu ditambah dan diperbaiki. Untuk itu saya mengharapkan inspirasi dari para pembaca dalam hal membantu menyempurkan makalah ini. Untuk terakhir kalinya saya berharap agar dengan hadirnya makalah ini akan memberikan sebuah perubahan khususnya dunia pendidikan. 


\section{DAFTAR PUSTAKA}

Feradhita. (2021, Mei 24). Pengertian Konsep Pemasaran dan 5 Konsep Penting didalmannya. Dipetik November 30, 2021, dari Logigue: https://www.logique.co.id/blog/2021/05/24/konseppemasaran/

Prawiro, M. (2020, Oktober 9). Pengertian Pemasaran : Ruang Lingkup, Fungsi, Tugas, dan Jenis Jenisnya. Dipetik November 30, 2021, dari Maxmonroe:

https://www.maxmanroe.com/vid/marketing/pengertian-pemasaran.html

Priharto, S. (2019, Agustus 2). Pengertian Pemasaran, Fungsi, dan Jenis Pemasaran dalam bisnis . Dipetik November 30, 2021, dari CPS Soft : 2. https://cpssoft.com/blog/bisnis/pengertianpemasaran-fungsi-dan-jenis-pemasaran-dalam-bisnis/

Suryadi, M. (2010, September 20). Makalah Tentang Pasar dan Pemasaran. Dipetik November 30, 2021, dari Miramedianisuryadi'S Blog: .

https://mirameidianisuryadi.wordpress.com/2010/09/29/makalah-tentang-pasar-

dan\%C2\%A0pemasaran/

Yahya, H. (2015, April 1). Makalah Pasar dan Pemasaran. Dipetik November 30, 2021, dari Faculty of Fisheries And Marine Science: 1. https://henitayahya.blogspot.com/2015/04/makalah-pasardan-pemasaran.html 